\title{
Evaluation of Active Ingredient and Grain Yield of Buckwheat Affected by Sowing date, Planting Pattern and Nitrogen in Summer Cultivation
}

\author{
Mohammad Reza Sobhani ${ }^{1}$, Amin Farnia ${ }^{1 *}$, Mojtaba Jafarzadeh Kenarsari ${ }^{1}$ \\ ${ }^{1}$ Department of Agronomy, Borujerd Branch, Islamic Azad University, Borujerd, Iran.
}

\section{ABSTRACT}

In order to evaluate the active ingredient, grain yield of common buckwheat (fagopyrum esculentum) affected by sowing date, planting pattern and nitrogen in summer cultivation, a field study was conducted during 2018 and 2019 in Agricultural Research Institute of Arak, Iran. The experimental design was regarded as the randomized complete blocks in the form of split-plot factorial with three replications. Planting pattern treatments as the primary factors included two levels of $50 \mathrm{~cm}$ mound with two $20 \mathrm{~cm}$ sowing rows $\left(\mathrm{P}_{1}\right)$ and $60 \mathrm{~cm}$ mound with three $15 \mathrm{~cm}$ sowing rows $\left(\mathrm{P}_{2}\right)$. Sowing date treatments included four levels of $20^{\text {th }} \mathrm{June}\left(\mathrm{D}_{1}\right), 5^{\text {th }} \mathrm{July}\left(\mathrm{D}_{2}\right), 20^{\text {th }} \mathrm{July}$ $\left(D_{3}\right)$ and $5^{\text {th }}$ August (D4) and nitrogen treatments included four levels of $0\left(\mathrm{~N}_{1}\right), 50\left(\mathrm{~N}_{2}\right), 100\left(\mathrm{~N}_{3}\right)$ and $150\left(\mathrm{~N}_{4}\right)$ $\mathrm{kg} \mathrm{ha}^{-1}$ considered as secondary factors. Results showed that the effects of planting dates, nitrogen and planting patterns have been significant on grain yield, rutin percent rates of leaves, stem, grain and flower. So, the highest rates of grain yield as $1967 \mathrm{~kg} \mathrm{ha}^{-1}$, leaf, stem, grain and flower rutin percent as $0.99,0.37,0.007$ and $1.35 \mathrm{mg}$ per $100 \mathrm{~g}$ of dry matter have been observed for the treatments of $\mathrm{P}_{2} \mathrm{D}_{1} \mathrm{~N}_{3}, \mathrm{P}_{2} \mathrm{D}_{4} \mathrm{~N}_{4}, \mathrm{P}_{1} \mathrm{D}_{4} \mathrm{~N}_{4}, \mathrm{P}_{1} \mathrm{D}_{4} \mathrm{~N}_{3}$ and $\mathrm{P}_{1} \mathrm{D}_{4} \mathrm{~N}_{3}$; respectively. Therefore, buckwheat with nutritional characteristics, adaptation, good yield as a new medicinal plant can enter the cultivation patterns in different regions of the world.

Key Words: Active ingredient, Nitrogen fertilizer, Rutin, Sowing rows, Summer cultivation

eIJPPR 2020; 10(5):270-284

HOW TO CITE THIS ARTICLE: Mohammad Reza Sobhani, Amin Farnia, Mojtaba Jafarzadeh Kenarsari (2020). "Evaluation of Active Ingredient and Grain Yield of Buckwheat Affected by Sowing date, Planting Pattern and Nitrogen in Summer Cultivation", International Journal of Pharmaceutical and Phytopharmacological Research, 10(5), pp.270-284.

\section{INTRODUCTION}

Buckwheat which has been scientifically named Fagopyrum esculentum can be considered as a yearling broad-leaved plant belonging to the family of Polygonaceae which is known as false Cereal. Planting of medicinal plants is likely to be significantly developed due to the needs of medicinal, nutritional, cosmetic and hygienic industries so that more researches and studies should be performed in this regard [1]. The use of plants as a phytochemical source has increased the popularity of this plant as a valuable medicinal plant. Therefore, due to the interest of farmers in cultivating this crop in recent years, the productivity and cultivated areas of this crop have increased worldwide [2]. Because biologic active compounds have many fans, and since these compounds vary depending on the location of cultivation, age and plant species, therefore, practical approaches are necessary to increase them [3]. Its seeds are used as a nutritional and medicinal product because of the rutin content of them [4]. Buckwheat also contains high level of rutin in nearly all organs, including seeds, cotyledons, leaves, stems, and flowers [5]. The flour obtained from this plant's seeds has a medical effect on controlling and improving diabetes and also treating marrow fibrosis, heart coronary and hypertension [4]. Quercetin glycoside in buckwheat is quercetin-3-O-rutinoside, also known as rutin. It is composed of the flavonoid quercetin and rutinose, which is a disaccharide of L-rhamnose and D-glucose [6].

Rutin has garnered much attention for the health benefits associated with its use as a supplement. Fortification of cereal-based foods with buckwheat bran could therefore

Corresponding author: Amin Farnia

Address: Department of Agronomy, Borujerd Branch, Islamic Azad University, Borujerd, Iran.

E-mail: $\bowtie$ aminfarnia @ yahoo.com

Relevant conflicts of interest/financial disclosures: The authors declare that the research was conducted in the absence of any commercial or financial relationships that could be construed as a potential conflict of interest.

Received: 21 July 2020; Revised: 22 October 2020; Accepted: 26 October 2020 
not only add value to a by-product of buckwheat milling but also create a functional food offering a variety of nutritional and health benefits [7]. Flavonoid and Rutin are used in clinical chemistry and human health due to their excellent pharmacological (vasoactive, antiviral, antiallergic and antiprotozoal) and physiological (antibacterial, anti-inflammatory and antitumor) activities $[8,9]$. Buckwheat is considered as a plant with a short growing season and its cultivation increasing worldwide [2]. In a study on buckwhaet, they reported a significant difference in the amount of plant rutin in different areas of cultivation [10]. Different dates of planting in various climatic conditions influence the length of plants' growth period and can play important roles in changing the plant effective material and production rates [1]. High temperature causes that buckwheat vegetative organs and leaves are burnt; therefore, it decreases the yield and quality of vegetative organs as well as their rutin rates. Reported that among the environmental factors, temperature is the most effective factor in the accumulation of flavonoids and rutin. Due to the fact that plant buckwheat is resistant to environmental conditions and tolerates high temperatures, it is possible to reduce the active ingredient [11]. Understanding how environmental factors affect the phytochemical production will be of great importance [12].

Selecting suitable sowing dates, various growth stages of plants will be in conformity with the appropriate environmental conditions which may enhance the photosynthesis efficiency and sufficient supply of photosynthetic materials as well as the yield. In European countries, suitable sowing dates are specified as the middle of May and July [13] and At a lower altitude, wheat rushes are usually planted in the months of May-August, while in higher altitudes, April-May, the optimal time for planting wheat raisins is optimal, the study said [14]. Examining the rutin percent of buckwheat with respect to a variety of sowing dates, they have stated that after the summer planting periods, the plant rutin rate may be the half of that given for the summer ones. Changing plant distances is used as a tool to increase or decrease plant density, so new innovations in plant production recommend the use of narrow row spacing [15].

Plants yield is resulted from the internal and external species contests to achieve the environmental potentials and thus, maximum yield can be obtained when these contests are minimized. One of the contest minimization ways is to have the accurate plant distribution in the desired area since the distance intervals between the planting rows and the plants in each row can determine the useful growing space and the resultant plant yield. Studying the number of plants buckwheat $(125,250,375$ and 500 plant $)$ and planting row intervals $(12,24,36$ and $48 \mathrm{~cm})$, the best yield was found while planting 125 plant at the intervals of
$36 \mathrm{~cm}$ [16]. It has been reported that the planting patterns play the influential roles in distributing the light considering the vegetation. The effects of environmental conditions are to be indicated in the stage of seeds filling through conducting a sowing date examination (in the middle of May) on the rows with the intervals of $12.5 \mathrm{~cm}$ along with 200 plants per hectare. In a report, $30 \mathrm{~cm}$ of 10 $\mathrm{cm}$ planting makeup in buckwheat and $20 \mathrm{~kg}$ of suitable nitrogen was reported [17].

Furthermore, uniform distribution of bushes in nearer planting rows leads to the more effective application of resources and delay of contest start point among species that may improve the light emission and enhance the net absorption of light. Such distribution can be achieved if the distance intervals of plants are equaled; in other words, it is called the uniform planting pattern. Applying such planting patterns, the contest to absorb the light will be minimized, the plant canopy is able to fully receive the available radiation, and the plant yield will be increased $[18,19]$. It may be given due to the changes of photosynthetic materials' allocation to vegetative and reproductive organs. Photosynthetic materials move towards the reproductive organs and as a result, the performance and yield of organs may be affected [20]. Another factor affecting the production and active ingredient of medicinal plants is the nutrients. Among growth suppliers of medicinal plants, nitrogen fertilizers are of high importance. Although they might be suggested for medicinal plants, their application should be done according to the above-mentioned facts because a fertilizer treatment may increase the crop yield whereas the amount of effective materials of medicinal plants will be reduced or some changes are to be occurred in the ingredients of effective medicinal materials considered as a disadvantage. It has been reported that high nitrogen consumption, due to increased vegetative growth and decreased lignin, increases the risk of plant dormancy and affects the amount of active ingredient [21]. As Salehi et al (2018) has presented the effects of various levels of nitrogen on Buckwheat's characteristics, nitrogen as the most important element to correct the nutrient status of the soil has the highest impacts on the increase of crop And competition for complex nutrient nutrients is on par with other competitions. [22]. In addition, high rates of nitrogen resulted in decreasing the rutin rate and increasing the biomass [23, 24]. Maximum yield has been given during hot and long days. Leaves and flowers' rutin rates followed the same trend, and the maximum rutin rate that is $5 \%$ was obtained [25]. Most rutin is accumulated in the inflorescence (up to $0 \cdot 12 \mathrm{mg} / \mathrm{g} \mathrm{dw}$ ), in stalks $(0 \cdot 004-0 \cdot 01$ $\mathrm{mg} / \mathrm{g} \mathrm{dw})$, upper leaves $(0 \cdot 08-0 \cdot 10 \mathrm{mg} / \mathrm{g} \mathrm{dw})$ and $0 \cdot 12-$ $0.36 \mathrm{mg} / \mathrm{g} \mathrm{dw}$ in grains depending on the variety and growth conditions $[26,27]$. Rutin content in vegetative mass of buckwheat (leaves, inflorescences and stem) 
ranges from 2 up to $9 \%$ [28], which may vary according to growth location and cultivar. It has been reported that many environmental factors affect the biosynthesis pathway of polyphenols, so it is difficult to manage agricultural operations under the influence of environmental factors. Therefore, with the help of various techniques such as time and method of planting and proper distribution of nutrients, we can take an effective step to reduce plant competition.

Given the growing need for healthy food and crop production alongside potential agricultural opportunities as basic agricultural policies, new crops with high crop yields, good quality, low water demand and multi-crop systems and their use in nutrition should be studied. Therefore, this research aimed to evaluate the effects of sowing date, planting pattern and nitrogen on quantitative grain yield and rutin percent in different parts of buckwheat. This review has been designed to highlight the chemical constituents and pharmacological effects of Fagopyrum esculentum as a promising plant for many pharmacological purposes as a commercial source of rutin or a functional food. In addition, because there is very little information about this plant in Iran and it is in accordance with the climatic conditions of Iran in terms of water shortage and is located in a dry and semi-arid region, therefore, it seems necessary to conduct this research.

\section{MATERIALS AND METHODS}

Field experiment was conducted by Agricultural Research Institute of Arak in a specific area located in northern latitudinal of $34^{\circ} 5^{\prime}$ and eastern longitudinal of $49^{\circ} 42^{\prime}$ that is $1757 \mathrm{~m}$ above sea level during 2018-2019. Some of the physic-chemical properties of the soil have been presented in (Table 1). The experimental design was a randomized complete blocks in the form of split-plot factorial with three replications. Planting treatment as the main factor was implemented at two levels including the mounds with the width of $50 \mathrm{~cm}$ associated with two planting rows regarding the distance intervals of $20 \mathrm{~cm}\left(\mathrm{P}_{1}\right)$ and those with the width of $60 \mathrm{~cm}$ along with three planting rows which are of the distance intervals of $15 \mathrm{~cm}\left(\mathrm{P}_{2}\right)$.

Table 1. Selected physico-chemical properties of soil

\begin{tabular}{ccc}
\hline Parameter & Unit & Unamended soil \\
\hline Soil depth & - & $0-20 \mathrm{~cm}$ \\
\hline $\mathrm{pH}$ & - & 7.9 \\
\hline $\mathrm{EC}$ & $\mathrm{dS} \mathrm{m}{ }^{-1}$ & 1.23 \\
\hline Sand & $\%$ & 30 \\
\hline Silt & $\%$ & 35 \\
\hline Clay & $\%$ & 35 \\
\hline Organic carbon & $\%$ & 0.6 \\
\hline Total N & $\%$ & 0.01 \\
\hline Total P & $\mathrm{ppm}$ & 15
\end{tabular}

\begin{tabular}{ccc}
\hline Total $\mathrm{K}$ & ppm & 290 \\
\hline $\mathrm{CaCO}_{3}$ & $\%$ & 10 \\
\hline
\end{tabular}

Sowing date and nitrogen treatments which may be considered as the minor elements are likely to be examined at four levels of dates and weights involving $20^{\text {th }}$ June $\left(D_{1}\right)$, $5^{\text {th }}$ July $\left(\mathrm{D}_{2}\right), 20^{\text {th }}$ July $\left(\mathrm{D}_{3}\right)$ and $5^{\text {th }}$ August $\left(\mathrm{D}_{4}\right)$ and $0 \mathrm{~kg}$ $\mathrm{ha}^{-1}\left(\mathrm{~N}_{1}\right), 50 \mathrm{~kg} \mathrm{ha}^{-1}\left(\mathrm{~N}_{2}\right), 100 \mathrm{~kg} \mathrm{ha}^{-1}\left(\mathrm{~N}_{3}\right)$ and $150 \mathrm{~kg} \mathrm{ha}^{-1}$ $\left(\mathrm{N}_{4}\right)$; respectively. Seeds of buckwheat were drill-seeded by hand. The buckwheat seed were obtained from Germany (Figure 1). With respect to the fixed density of 100 plants per square meter, the distances between the planting lines were specified as 4 and $5 \mathrm{~cm}$ for treatments of $P_{1}$ and $P_{2}$; respectively. Dimensions of each plot for the planting patterns of $P_{1}$ and $P_{2}$ have been determined as $3 \times 2.5$ and $3 \times 3 \mathrm{~m}$ consisting of 5 planting rows. Distribution of nitrogen fertilizer (on the basis of urea fertilizer) was done in 2 stages: first and second stages included 4-leaved and 8-leaved plants; respectively. Irrigation on the farm was done by the drip method. Irrigation intervals were carried out according to climatic conditions between 5 or 7 days based on plant needs. On August $8^{\text {th }}$, and September $2^{\text {nd }}, 11^{\text {th }}$ and $20^{\text {th }}$ after plants being harvested in the first year, and on August $21^{\text {st }}$ and $31^{\text {st }}$ and September $12^{\text {th }}$ and $24^{\text {th }}$ in the second year; the shoots, leaves, seed were sampled separately.

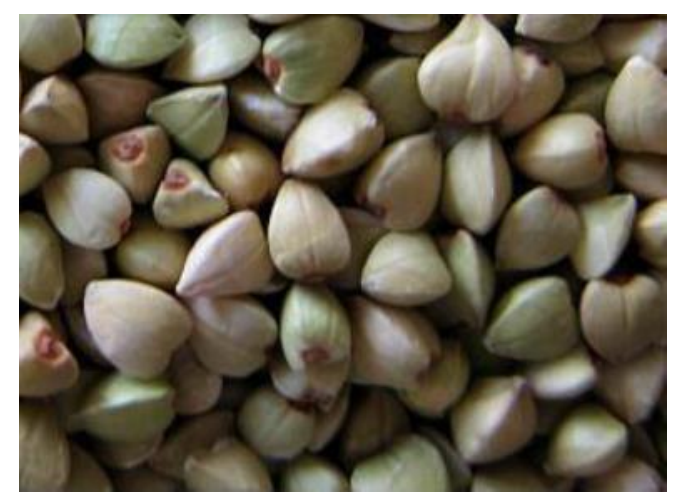

(a)

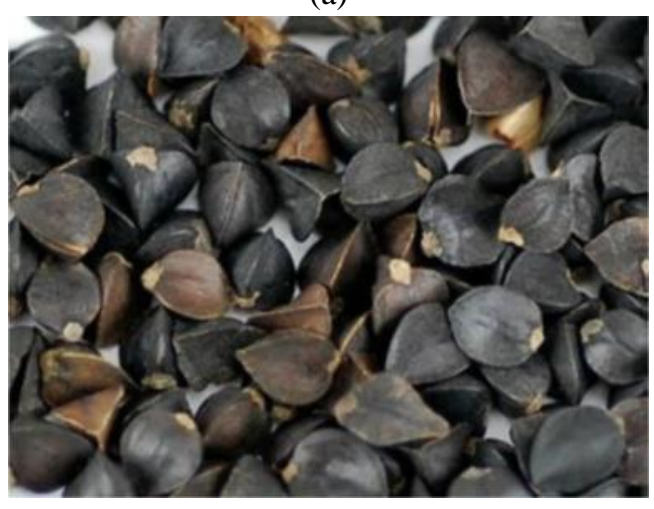

(b)

Figure 1. Buckwheat seed

In this research, rutin extraction and measurement were conducted in the laboratory of Islamic Azad University, 
Arak [29, 30]. Rutin was measured using HPLC (Bio-tek Kontron 535) instrument.

Samples of leaves, stems, flowers, and seeds were milled after drying. Then, $3 \mathrm{~g}$ of each sample was poured into a balloon and $30 \mathrm{ml}$ of methanol solution was added at a proportion of $80-20 \%$.

The extraction protocol of $80 \%$ methanol using ultrasound treatment was selected for ease of use and to facilitate rutin stability during extraction. Previous literature has also noted the effectiveness of ultrasound-assisted extraction and organic solvent concentrations in the range of 70-80\% for removing rutin from other plant materials [31, 32].

The resulted mixture was placed on the stirrer for 20 minutes and then was passed through the filter paper, and the filtrate was poured into a graduated cylinder with cap and stored in the refrigerator. To obtain the moisture content of the samples, $5 \mathrm{~g}$ of each sample was placed at $75^{\circ} \mathrm{C}$. After 24 hours, the samples were weighed, and the weight difference of the samples was recorded as a percentage of moisture. To prepare the standard sample, 25 and $50 \mathrm{mg}$ of standard rutin with $95 \%$ purity prepared by Merck Company, was diluted to $25 \mathrm{ml}$ by adding methanol.
$80 \%$ methanol was used to adjust the non-polar mobile phase of the HPLC machine, and $0.1 \mathrm{mM}$ phosphoric acid was used in the mobile phase. The prepared solution of each of the samples and the standard sample were also filtered before injection by special filters mounted on a syringe. The injection volume of the standard sample and the obtained samples was 10 microliters, which was injected by special syringes into the machine, and the resulted curves and numbers were applied to the final calculation according to the following formula. Elution time for rutin was 9.5 minutes (Figure 2).

$$
\text { Rutin }(\%)=\frac{\mathrm{a} \times \mathrm{V}}{\mathrm{V} \times \mathrm{m}} \times 100
$$

Where: a: rutin rate reported by HPLC system according to mgr.

$\mathrm{V}$ : final mass obtained from the extraction according to $\mathrm{mL}$.

$\mathrm{v}$ : injection mass from the desired sample according to $\mathrm{mL}$. M: dry weight for the extraction according to mgr.

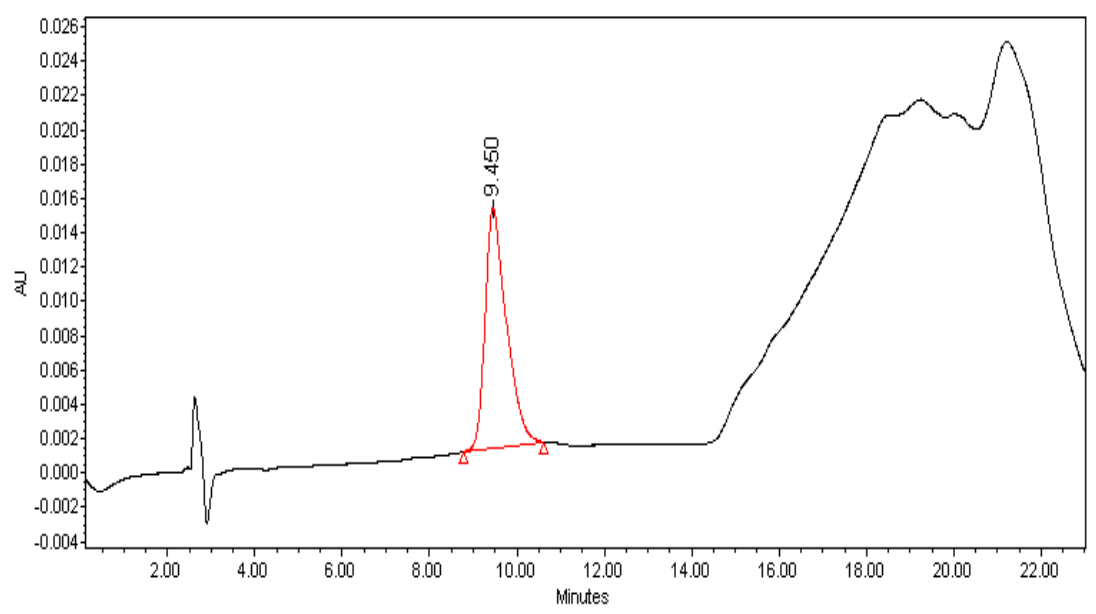

Figure 2. HPLC chromatogram of a rutin standard in $80 \%$ methanol

To calculate the final grain yield, the sum of seeds per a square meter (based on $12 \%$ of humidity) regarded as the grain yield criterion is likely to be computed when $75 \%$ of seeds' maturity is given in every plot. The statistical calculations and analysis of variance were performed using the SAS software (SAS 9.1.3). The averages have been compared in the experiment by the use of Duncan's multiple-range test at the probability level of $5 \%$.

\section{RESULTS AND DISCUSSION}

\section{Flower rutin percent (\%)}

Flower rutin percent has not been affected by the year, and the interactions between the year and treatments, the year and planting patterns, the year and sowing dates and the year and nitrogen fertilizer were not significant, but the year had a significant relationship with the replication. Considering the treatments' relationships, nitrogen fertilizer, sowing dates and planting patterns had significant relationships. The highest flower rutin percent was given as $1.36 \mathrm{mg}$ at $100 \mathrm{~g}$ of dry matter relevant to the treatment of $\mathrm{P}_{1} \mathrm{D}_{3} \mathrm{~N}_{3}$ regarding the triple interaction of treatments (Table 2 and Table 3 ).

Considering the accumulation of secondary metabolites, it can be concluded that when first metabolism having the maximum activity rate finishes the plant vegetative growth, a great deal of resultant materials and energy will be transferred to activate the generative and flowering stages. If the plant encounters the environmental tensions including a temperature one, it will be forced to consume 
International Journal of Pharmaceutical and Phytopharmacological Research (elJPPR) | October 2020| Volume 10| Issue 5| Page 270-284 Mohammad Reza Sobhani, Evaluation of Active Ingredient and Grain Yield of Buckwheat Affected by Sowing date, Planting Pattern and Nitrogen in Summer Cultivation

the physiological storages during a vital stage and instead, high rates of remaining obtained from the first metabolism may be remained as secondary metabolites.

Table 2. Mean squares from analysis of variance of grain yield, harvest index and rutin percent

\begin{tabular}{|c|c|c|c|c|c|c|}
\hline Source of variation & $\mathrm{df}$ & grain yield & Lefa rutin & stem rutin & Flower rutin & grain rutin \\
\hline Year & 1 & $722.01^{*}$ & $0.056^{*}$ & $0.084^{* *}$ & $0.001^{\text {n.s }}$ & $0.002^{* *}$ \\
\hline Year $\times$ Replication & 1 & $12426.89^{\mathrm{ns}}$ & $0.001^{\text {n.s }}$ & $0.036^{* *}$ & $2.79^{* *}$ & $0.000003^{\mathrm{n} . \mathrm{s}}$ \\
\hline Planting pattern & 1 & $96241.3^{*}$ & $0.0005^{\mathrm{n} . \mathrm{s}}$ & $0.0002^{\text {n.s }}$ & $0.001^{\text {n.s }}$ & $0.000001^{\mathrm{n} . \mathrm{s}}$ \\
\hline Year $\times$ planting pattern & 3 & $1.11^{*}$ & $1.34^{\text {*** }}$ & $0.180^{* *}$ & $1.903^{*}$ & $0.00001^{\text {n.s }}$ \\
\hline Year $\times$ planting pattern $\times$ Replication & 3 & $6245.74^{\mathrm{ns}}$ & $0.100^{* *}$ & $0.013^{* * *}$ & $0.171^{* *}$ & $0.00001^{* *}$ \\
\hline Sowing date & 3 & $2484113.8^{*}$ & $0.151^{*}$ & $0.011^{*}$ & $1.38^{* *}$ & $0.00001^{\mathrm{n} . \mathrm{s}}$ \\
\hline Nitrogen fertilizer & 3 & $155002.5^{*}$ & $0.058^{\mathrm{n} . \mathrm{s}}$ & $0.014^{* *}$ & $0.495^{* *}$ & $0.00002 *$ \\
\hline Sowing date $\times$ Planting pattern & 9 & $738200.8^{*}$ & $0.493^{* *}$ & $0.010^{* * *}$ & $0.089^{* *}$ & $0.00002^{* *}$ \\
\hline Planting pattern $\times$ Nitrogen fertilizer & 3 & $756578.33^{*}$ & $0.015^{*}$ & 0.001 n.s & 0.003 n.s & $0.00001^{* *}$ \\
\hline Sowing date $\times$ nitrogen & 3 & 19885.03* & $0.040^{* *}$ & $0.0001^{\mathrm{n} . \mathrm{s}}$ & $0.001^{\mathrm{n} . \mathrm{s}}$ & $0.000004^{*}$ \\
\hline Sowing date $\times$ year & 9 & $0.002^{\mathrm{ns}}$ & $0.016^{*}$ & $0.0003^{\mathrm{n} . \mathrm{s}}$ & $0.003^{\mathrm{n} . \mathrm{s}}$ & $0.000003^{*}$ \\
\hline Nitrogen $\times$ year & 3 & $0.002^{\mathrm{ns}}$ & $0.007^{\mathrm{n} . \mathrm{s}}$ & $0.001^{* *}$ & $0.004^{\mathrm{n} . \mathrm{s}}$ & $0.00003^{\text {*** }}$ \\
\hline Nitrogen $\times$ year $\times$ sowing date & 3 & $0.003^{\mathrm{ns}}$ & $0.017^{*}$ & $0.0002^{\mathrm{n} . \mathrm{s}}$ & $0.0005^{\mathrm{n} . \mathrm{s}}$ & $0.000001^{\mathrm{n} . \mathrm{s}}$ \\
\hline Year $\times$ sowing date $\times$ planting pattern & 9 & $0.002^{\mathrm{ns}}$ & $0.095^{* * *}$ & $0.018^{* *}$ & $0.261^{* *}$ & $0.000009^{*}$ \\
\hline Year $\times$ sowing date $\times$ nitrogen & 9 & $0.003^{\mathrm{ns}}$ & $0.011^{\mathrm{n} . \mathrm{s}}$ & $0.0001^{\mathrm{n} . \mathrm{s}}$ & $0.004^{\mathrm{n} . \mathrm{s}}$ & $0.00002^{\mathrm{n} . \mathrm{s}}$ \\
\hline Sowing date $\times$ nitrogen $\times$ planting pattern & 9 & $553755.8^{* *}$ & $0.006^{* *}$ & $0.0002^{* *}$ & $0.005^{* *}$ & $0.0009^{* *}$ \\
\hline Year $\times$ sowing date $\times$ nitrogen $\times$ planting pattern & 9 & $6375189.7^{* *}$ & $0.511^{* *}$ & $15.42^{*}$ & $2.68^{\mathrm{ns}}$ & $1.09^{\mathrm{ns}}$ \\
\hline Test error & 120 & 20.46 & 16.58 & 19.27 & 10.48 & 23.23 \\
\hline
\end{tabular}

$\mathrm{Ns}, *, * *$. Non-significant, significant at level of $\mathrm{p}<0.05,0.01$, respectively

These metabolites will considerably concentrate and accumulate in some especial points of plant vegetative body. As mentioned before, this phenomenon is of lots of economic consequences. Based on the report, rutin content of the flower part is higher than that of other parts of buckwheat-leaf, seeds, or roots. About $10 \%$ of rutin (per dry weight) is found in buckwheat flower and leaf [33]. It has been reported that the rutin amount of buckwheat plant at the beginning of flowering is the highest. [24]. It has been reported that the amount of rutin varies between the organs of the wheatgrass plant and is higher in the flower than in the leaf [34]. Therefore, among the interactions of treatments, planting pattern $\mathrm{P}_{1}$ is of most appropriate conditions for the third sowing date and suitable use of 100 $\mathrm{kg}$ of nitrogen to obtain the highest rutin percent of the plant (Figure 3). Therefore, it seems that on the third planting date, the average suitable temperature for suitable growing conditions and further production of flower buds has been provided, which is consistent with the results of researchers who reported the effect of temperature on the amount of active substance accumulation in plants [21].

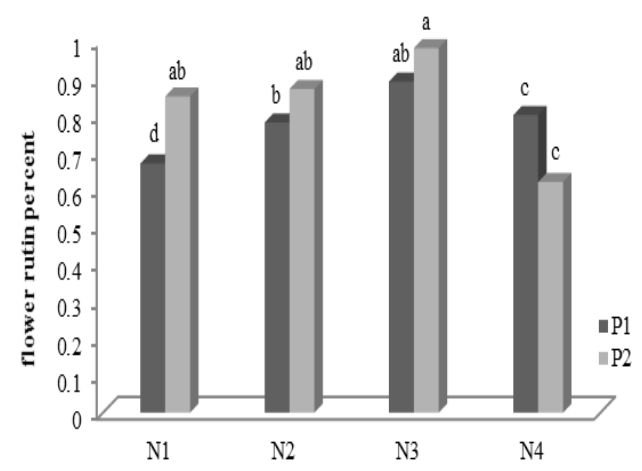

Figure 3. Interaction of planting pattern and nitrogen fertilizer of flower rutin.

Regarding first and second sowing dates, the number of generative units and flowers and flower rutin percent are likely to be reduced due to high temperature during vegetative and generative stages and lack of respiration balance between production and consumption. It was reported that the optimum temperature for optimal accumulation of writing is $25^{\circ} \mathrm{C}$ and with increasing temperature from $35^{\circ} \mathrm{C}$ the written content decreases [11]. In a review of biosynthesis processes and flavonoid 
accumulation during the growth and development of buckwheat plants under the influence of external factors, these factors were reported to be effective in the amount of rutin in the plant [35]. Omidbeigi and Mastro (2004) performed an examination on the buckwheat yield of 7 cultivars in various sowing dates in Iran, and presented that $25^{\text {th }}$ June is the best planting date with respect to the rutin percent.

One of the effective factors in optimal growing conditions is to create a suitable space between the plant community to minimize competition. In this regard, choosing the right planting arrangement (square planting arrangement) can achieve this result. The lack of competition between single plants has been able to store the highest number of flowers and therefore the highest amount of rutin. The highest rutin percent buckwheat as $0-1.22$ has been reported [36]. In the planting pattern of $\mathrm{P}_{1}(50 \mathrm{~cm}$ mounds with 2 planting rows and the intervals of $20 \mathrm{~cm}$ ), due to high contest of single-bush plants, generative stage will begin earlier and the maximum number of flowers may be achieved while harvesting the flowers to measure the rutin percent. In a study on how to grow buckwheat, they reported that planting two rows in dry and semi-arid areas were the best way to optimally consume soil nitrogen [37]. In relation to nitrogen treatment, as reported, nutrients are one of the most important factors affecting the amount of active ingredient. Therefore, in this study, using $100 \mathrm{~kg}$ of plant nitrogen, it has been able to store the most effective material in the flower structure. Nitrogen fertilizers have been reported to affect the rutin content of buckwheat [38]. Therefore, it seems that the interaction of crop and environmental factors, along with the vegetative habit of the plant has been able to produce an acceptable percentage of rutin despite cultivation in summer. Correlation coefficients of trats showed that, flower rutin percent is significantly correlated with the grain yield (0.138). It can be concluded that the increase in the number of ears will lead to produce more flowers in the plant and as a result, flower rutin percent as well as the yield may be enhanced (Table 4).

\section{Leaf rutin percent (\%)}

Investigating and analyzing the combined data suggested that leaf rutin percent is influenced by the year which has no significant interactions with the desired treatments, planting pattern, sowing date and the replication whereas it is significantly related to nitrogen fertilizer. Sowing date and planting pattern, sowing date and nitrogen fertilizer have no significant correlation while nitrogen fertilizer and planting pattern are significantly correlated. Nitrogen fertilizer and sowing date are meaningfully related while planting pattern is not significant (Table 2). According to (Table 3), regarding the third order interaction, the highest leaf rutin percent as $0.99 \%$ may be attributed to the treatment of $\mathrm{P}_{2} \mathrm{D}_{4} \mathrm{~N}_{4}$. Results indicated that in the fourth sowing date, suitable temperature and day length increased the length of growing period and leaf area index. In the first and second sowing dates, high temperature caused the decrease of leaf rutin as compared to vegetative stages.

In a study on wheat beech, they reported a significant difference in the amount of plant rutin in different areas of cultivation [10]. Rutin extraction and measurement in the plants obtained from different cultivations showed that the current rutin content of the leaves will be decreased as the weather gets warm and the day length increases so that the highest and lowest rates can be determined for the planting periods of March and July [39]. Through examining buckwheat rutin percent in different sowing dates, it has been reported that rutin percent in the sowing dates after summer is the half of that in summer ones. They proposed a positive correlation between the days of sowing date and rutin percent. The rutin content of the leaves was reported as $3417 \mathrm{mg}$ per $100 \mathrm{~g}$ of leaf dry weight [34]. It is reported that this plant can be cultivated in the summer due to the resistance of buckwheat to heat [40]. In an experiment, the highest concentration of rutin on the leaves and then the inflorescence, stems and seeds were cut. Solidarity analysis shows that rutin synthesis of leaves leads to other parts of the plant. Therefore, improving the proper conditions of crop and food management, despite the effect of interaction with environmental factors, will play a significant role in increasing plant biomass and as a result, more photosynthesis and increase in secondary metabolites [41]. It was reported that planting rows of $12.5 \mathrm{~cm}$ with a density of 400 seeds per square meter are suitable due to the greater number of plants in the amount of rutin production of buckwheat leaves [42].

Table 3. Comparison of the means for grain yield and rutin percent

\begin{tabular}{cccccc}
\hline Treatment & $\begin{array}{c}\text { grain yield } \\
\left(\mathrm{kg} \mathrm{ha}^{-1}\right)\end{array}$ & $\begin{array}{c}\text { Leaf rutin } \\
\text { percent }\end{array}$ & $\begin{array}{c}\text { Stem rutin } \\
\text { percent }\end{array}$ & $\begin{array}{c}\text { Flower rutin } \\
\text { percent }\end{array}$ & $\begin{array}{c}\text { grain rutin } \\
\text { percent }\end{array}$ \\
\hline P1D1N1 & $1570.2 \mathrm{~b}$ & $0.56 \mathrm{ef}$ & $0.06 \mathrm{lk}$ & $0.69 \mathrm{ih}$ & $0.001 \mathrm{kj}$ \\
\hline P1D1N2 & $150.3 \mathrm{~b}$ & $0.55 \mathrm{ef}$ & $0.08 \mathrm{ef}$ & $0.50 \mathrm{~lm}$ & $0.004 \mathrm{ef}$ \\
\hline P1D1N3 & $1810 \mathrm{ab}$ & $0.59 \mathrm{~d}$ & $0.09 \mathrm{ef}$ & $0.42 \mathrm{po}$ & $0.005 \mathrm{ec}$ \\
\hline P1D1N4 & $1793 \mathrm{ad}$ & $0.30 \mathrm{mk}$ & $0.04 \mathrm{on}$ & $0.42 \mathrm{po}$ & $0.005 \mathrm{ef}$ \\
\hline P1D2N1 & $857 \mathrm{fj}$ & $0.21 \mathrm{mk}$ & $0.08 \mathrm{ij}$ & $0.99 \mathrm{c}$ & $0.002 \mathrm{ij}$ \\
\hline
\end{tabular}


International Journal of Pharmaceutical and Phytopharmacological Research (elJPPR) | October 2020| Volume 10| Issue 5| Page 270-284 Mohammad Reza Sobhani, Evaluation of Active Ingredient and Grain Yield of Buckwheat Affected by Sowing date, Planting Pattern and Nitrogen in Summer Cultivation

\begin{tabular}{|c|c|c|c|c|c|}
\hline P1D2N2 & $961.6 f$ & $0.33 \mathrm{hk}$ & $0.05 \ln$ & $0.99 \mathrm{c}$ & $0.007 \mathrm{ba}$ \\
\hline P1D2N3 & 973.7 af & $0.35 \mathrm{hi}$ & $0.03 \mathrm{ln}$ & $1.16 \mathrm{~b}$ & $0.001 \mathrm{kj}$ \\
\hline P1D2N4 & $963.2 \mathrm{ef}$ & $0.32 \mathrm{jk}$ & $0.03 \mathrm{o}$ & $1.09 \mathrm{~b}$ & $0.004 \mathrm{ef}$ \\
\hline P1D3N1 & $893.7 \mathrm{ej}$ & $0.15 \mathrm{ml}$ & $0.061 \mathrm{j}$ & $0.35 \mathrm{pq}$ & $0.002 \mathrm{ij}$ \\
\hline P1D3N2 & 843.6 af & $0.43 \mathrm{hf}$ & $0.07 \mathrm{lk}$ & $0.56 \mathrm{~lm}$ & $0.003 \mathrm{ef}$ \\
\hline P1D3N3 & $874 \mathrm{j}$ & $0.83 \mathrm{bc}$ & 0.9 ef & $1.36 \mathrm{a}$ & $0.004 \mathrm{ef}$ \\
\hline P1D3N4 & $857 \mathrm{ab}$ & $0.42 \mathrm{hf}$ & 0.08 ih & $0.780 \mathrm{~d}$ & $0.004 \mathrm{ef}$ \\
\hline P1D4N1 & 910 ej & $0.92 \mathrm{ba}$ & $0.11 \mathrm{~d}$ & $0.89 \mathrm{~d}$ & $0.005 \mathrm{ec}$ \\
\hline P1D4N2 & $940.3 \mathrm{ej}$ & 0.49 ef & $0.17 \mathrm{c}$ & $0.73 \mathrm{gh}$ & $0.007 \mathrm{a}$ \\
\hline P1D4N3 & $990.3 \mathrm{hj}$ & $0.18 \mathrm{mk}$ & $0.19 \mathrm{~b}$ & $0.66 \mathrm{ij}$ & $0.002 \mathrm{ij}$ \\
\hline P1D4N4 & $957 \mathrm{hj}$ & $0.93 \mathrm{ba}$ & $0.37 \mathrm{a}$ & $0.52 \mathrm{~lm}$ & $0.001 \mathrm{k}$ \\
\hline P2D1N1 & $1112 \mathrm{bi}$ & $0.48 \mathrm{hf}$ & $0.04 \ln$ & $0.581 \mathrm{j}$ & 0.003 if \\
\hline P2D1N2 & $1315.7 b c$ & $0.52 \mathrm{ef}$ & $0.04 \ln$ & 0.46 no & $0.004 \mathrm{ef}$ \\
\hline P2D1N3 & $1967 \mathrm{a}$ & $0.54 \mathrm{ef}$ & $0.05 \mathrm{lk}$ & $0.55 \mathrm{~lm}$ & $0.006 \mathrm{bc}$ \\
\hline P2D1N4 & $1433.7 \mathrm{bc}$ & $0.24 \mathrm{mk}$ & 0.03 on & $0.36 \mathrm{pq}$ & $0.004 \mathrm{ef}$ \\
\hline P2D2N1 & 9067 bi & $0.22 \mathrm{mk}$ & $0.02 \mathrm{o}$ & $0.83 \mathrm{df}$ & $0.003 \mathrm{ef}$ \\
\hline P2D2N2 & $933.7 \mathrm{fj}$ & $0.31 \mathrm{jk}$ & $0.05 \mathrm{lk}$ & $0.86 \mathrm{de}$ & $0.003 \mathrm{ef}$ \\
\hline P2D2N3 & 893.7 bj & $0.50 \mathrm{ef}$ & $0.06 \mathrm{ij}$ & $0.98 \mathrm{c}$ & $0.004 \mathrm{ef}$ \\
\hline $\bar{P} 2 \mathrm{D} 2 \mathrm{~N} 4$ & $790 \mathrm{ch}$ & $0.31 \mathrm{jk}$ & $0.04 \ln$ & $0.92 \mathrm{dc}$ & $0.003 \mathrm{ef}$ \\
\hline P2D3N1 & 848 bh & $0.15 \mathrm{~m}$ & $0.051 \mathrm{j}$ & $0.30 \mathrm{q}$ & $0.005 \mathrm{ef}$ \\
\hline P2D3N2 & $740 \mathrm{bf}$ & $0.41 \mathrm{hf}$ & $0.052 \mathrm{lk}$ & $0.27 \mathrm{q}$ & $0.004 \mathrm{ef}$ \\
\hline P2D3N3 & $760.3 \mathrm{ch}$ & $0.56 \mathrm{ef}$ & $0.10 \mathrm{ed}$ & $1.37 \mathrm{a}$ & $0.004 \mathrm{ef}$ \\
\hline P2D3N4 & $857 \mathrm{di}$ & $0.29 \mathrm{mk}$ & $0.30 \mathrm{mn}$ & $0.61 \mathrm{ij}$ & $0.006 \mathrm{bc}$ \\
\hline P2D4N1 & $922 \mathrm{fj}$ & $0.79 \mathrm{bc}$ & $0.93 \mathrm{ef}$ & $0.52 \mathrm{~lm}$ & $0.003 \mathrm{ef}$ \\
\hline P2D4N2 & $957 \mathrm{cf}$ & $0.59 \mathrm{ed}$ & $0.19 \mathrm{~b}$ & $1.36 \mathrm{a}$ & $0.002 \mathrm{ij}$ \\
\hline $\mathrm{P} 2 \mathrm{D} 4 \mathrm{~N} 3$ & $979 \mathrm{cf}$ & $978 \mathrm{cf}$ & $0.09 \mathrm{ed}$ & $0.19 \mathrm{~b}$ & $0.74 \mathrm{gf}$ \\
\hline P2D4N4 & $825 \mathrm{bh}$ & $0.99 \mathrm{a}$ & $0.02 \mathrm{o}$ & $0.87 \mathrm{dg}$ & $0.001 \mathrm{k}$ \\
\hline
\end{tabular}

Means with different letters in each column denoted statistically difference between treatments according to Duncan multiple range test $(\mathrm{P}<0.05) \mathrm{P} 1$ and $\mathrm{P} 2$ were planting treatment mounds with the width of $50 \mathrm{~cm}$ associated with two planting rows regarding the distance intervals of $20 \mathrm{~cm}$ and those with the width of $60 \mathrm{~cm}$ along with three planting rows which are of the distance intervals of $15 \mathrm{~cm}$. D1, D2, D3 and D4 were sowing date 20th June, 5th July, 20th July and 5th August. N1, N2, N3 and N4 were nitrogen treatments $0,50,100$ and $150 \mathrm{~kg} \mathrm{ha}^{-1}$.

Results showed that the maximum yield of dry matters has been obtained from hot and long days. Flowers and leaves' rutin rates followed the same trend and the highest rutin rate computed as 5\% was achieved from one of the cultivars during hot and long days [38]. The results, according to other researchers, show that planting dates in the summer, when the leaves are at their maximum growth, can increase the enzymatic activity of secondary metabolites. Establishing a general relationship between fine and gross production rates in this plant can lead us to gain the best accumulation and planting pattern with respect to the total leaf index specified as a criterion to measure photosynthesis and biomass production (including metabolic biomass i.e. optimum rutin production). In this respect, the planting pattern of $\mathrm{P}_{2}(60$ $\mathrm{cm}$ mounds with 3 rows and $15 \mathrm{~cm}$ distance intervals) may increase the eco-physiological relationships between the inputs and consequently, lead to the same results regarding the metabolic biomass production (rutin). In report, most rutin is accumulated in the upper leaves $(0.08-0.10 \mathrm{mg} / \mathrm{g}$ dw) [43]. Omidbeigi and Zakizadeh (2002) studied the effects of different planting accumulations on vegetative and generative yield and rutin rates in the buckwheat plant, and found that the density of 33.3 plants per $\mathrm{m}^{2}$ had the highest rate of dry matter in the vegetative body while having the lowest rutin rate. However, the accumulation of 100 plants per $\mathrm{m}^{2}$ showed the reversed results. It has been reported that in high densities, the amount of rutin in the organs of the buckwheat plant decreases [44]. It was reported that the percentage of rutin performance in buckwheat, raisins was higher in narrow planting rows [17].

Regarding the results of nitrogen fertilizer levels and leaf rutin percent, it may be seen that $150 \mathrm{~kg}$ of nitrogen can increase the vegetative sprouts on the branches and leaf production in the plant; in other words, the leaf rutin percent will be enhanced as compared to nitrogen treatments of 0,50 and $100 \mathrm{~kg}$ (Figure 4). Maybe, high 
nitrogen consuming and high temperature make reactions in the summer planting period. Wagenbreth et al (1996) reported the numbers of buckwheat and leaf rutin percent as 2 to $9 \mathrm{~m}$ gr at $100 \mathrm{gr}$ of dry matter [45]. Marquard and Kroth (2001) found no significantly different relationships between nitrogen fertilizer and rutin percent in the buckwheat [46]. Honermier and Wagenbreth (2000) have seen the increase of rutin percent as 18 to 29 in the buckwheat using 0 to $90 \mathrm{~kg} \mathrm{ha}^{-1}$ of nitrogen. Studying 7 cultivars of buckwheat and 2 levels of nitrogen fertilizer, the highest leaf rutin percent was measured as $0.61 \%$ for the cultivar of aelita using $50 \mathrm{~kg}$ of nitrogen [47]. Kwang Jin Chang et al (2004) have examined 2 cultivars of buckwheat on 4 accumulations and 5 fertilizer levels in Korea and suggested that fertilizer levels are of the highest rutin as $1887 \mathrm{~m}$ gr relevant to $30 \times 60$ accumulation for 100 gr of dry matter so that the highest rutin rates were 1839 and $1934 \mathrm{~m}$ gr for $100 \mathrm{gr}$ of dry matter without using the fertilizer [48]. In an experimental study, three planting arrangements $30 \times 10 \mathrm{~cm}, 30 \times 15 \mathrm{~cm}$ and $30 \times 20$ and the amount of N-P-K mixed fertilizers reported the best planting arrangement $30 \times 10 \mathrm{~cm}$ and $35 \mathrm{~kg}$ nitrogen to increase the rutin content in buckwheat plants [17]. Correlation coefficients of plant traits have been demonstrated in (Table 4) as the leaf rutin percent has a positive correlation with the rutin rates of grain (0.06), flowers $(0.13)$ while negatively correlated with the stem rutin percent (-0.09). Above correlations are the indicatives of plant rutin and its relationships with all the studied traits. Regarding the fact that the grain is the product of photosynthetic activities of vegetative organs especially leaves, high correlations of these qualities should be expected, and it indicates that in order to achieve higher yields, the plants having good chlorophyll development and appropriate vigor are required.

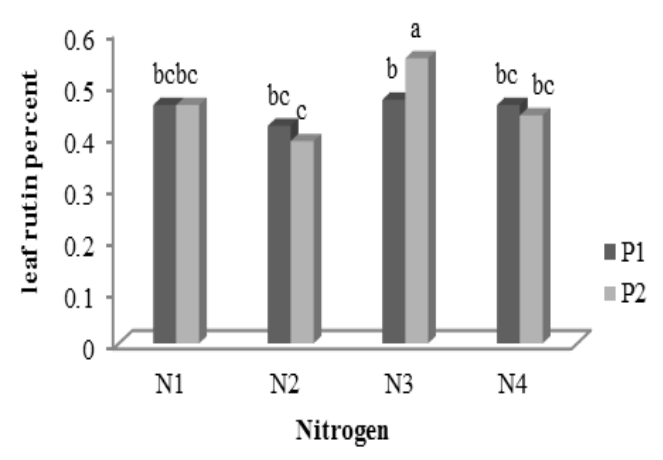

Figure 4. Interaction of planting pattern and nitrogen fertilizer of flower rutin.

Negative correlation of stem rutin percent suggests that more leaves (leaf to stem ratio), more stored dry matter in the leaves that results in the enhancement of leaf rutin percent as compared to the stem rutin percent. Besides, most of red light may be absorbed by the upper parts of each bush and the light absorbed by the lower ones considerably contain the wavelengths of blue and ultraviolet spectra. It is likely to increase the rutin rate of lamina in comparison with the stem.

\section{Stem rutin percent (\%)}

Results of data combined analyses have indicated that stem rutin percent has been influenced by the year and there were interactions between the year and planting patterns. Among the treatments' interactions, sowing dates were significantly correlated with the planting pattern and nitrogen fertilizer while planting pattern was of a meaningful interaction with nitrogen fertilizer. Considering the treatments' relationships, nitrogen fertilizer, sowing dates and planting patterns were significantly related (Table 2). As (Table 3) has already shown, the highest stem rutin percent was given as $0.37 \mathrm{mg}$ at $100 \mathrm{~g}$ of dry matter relevant to the treatment of $\mathrm{P}_{1} \mathrm{D}_{4} \mathrm{~N}_{4}$ with regard to the third order interaction of treatments.

This result suggests that the fourth sowing date was more suitable because of temperature balance between the vegetative activities and necessary enzymes. Regarding other sowing dates, high temperature, the increase of respiration and the decrease of photosynthesis have caused the reduction of stem diagonal and height as well as the storage capacity. It was reported that the date of planting did not affect the amount of rutin stem [49]. Due to the increase in growth in the conditions of the fourth planting date, which is the result of increasing the plant's metabolite, so secondary metabolites also increase Safe use of the stem. Therefore, in this study, planting dates have been effective in the rutin of the stem. It has been reported that the amount of rutin of the buckwheat plant is directly related to the height of the cultivation site and the rate of return is higher in low altitude and in higher temperature conditions [50]. In a report, the content of rutin in the buckwhaet was announced to be in the range of 3-6\% of dry weight [51]. It was reported that the cultivated area and growth stages of the buckwheat plant affect the rutin percentage of plant organs [49]. Changing plant distances is used as a tool to increase or decrease plant densi [15]. The best planting pattern has been introduced as the one which can be associated with the most appropriate bush distribution in order to achieve high rates of production and optimum use of existing inputs. In this regard, the planting pattern of $\mathrm{P}_{1}(50 \mathrm{~cm}$ mounds with two rows having the intervals of $20 \mathrm{~cm}$ ) has been able to keep balance between the intakes and the formation of maximum leaf area index as a production unit which has consequently related to high number of stems, thicker ones and finally, high storage rate of rutin percent. Based on the report, most rutin were accumulated in the stem $(0.004-0.01 \mathrm{mg} / \mathrm{g} \mathrm{dw})$ [52] 
Beside that report, growth conditions were effective in the percentage of rutine $[26,27]$. They reported that at higher densities, the stems became narrower, resulting in less active material storage [53]. Planting date and planting density have been reported to have a significant effect on the rutin content of buckwheat [38]. Nitrogen is one of the most important elements in plant nutrition and is one of the components of many important compounds such as proteins, nucleic acids, some hormones, chlorophyll and other types of primary and secondary constituents of plants.

Nitrogen is an essential element in increasing photosynthetic activity in plants, which in turn results in photosynthetic activity, an increase in primary metabolites, and consequently an increase in secondary metabolites. In this study, the use of $150 \mathrm{~kg}$ of plant nitrogen was able to have the highest amount of secondary (rutin) storage metabolites in the stem. Regarding the results of the nitrogen fertilizer levels and stem rutin percent, it could be found that the interaction between sowing dates and planting patterns using higher rates of nitrogen $(150 \mathrm{~kg})$ has been able to show their effects by increasing the stem rutin percent (Figure 5). Nitrogen fertilizers have been reported to affect the rutin content of buckwheat $[22,38]$.

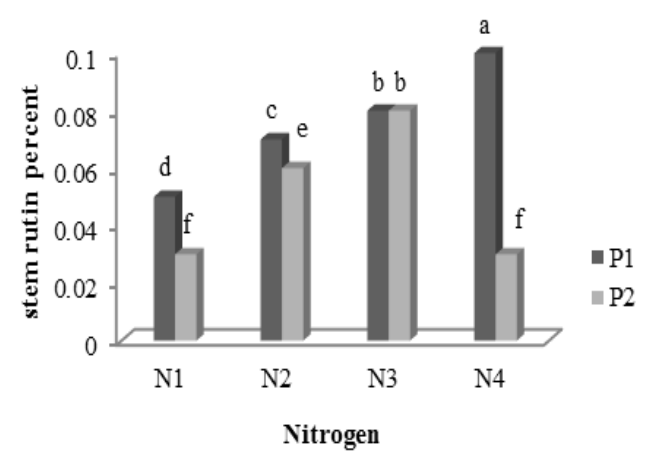

Figure 5. Interaction of planting pattern and nitrogen fertilizer of flower rutin.

As the effects of nutrition on buckwheat rutin percent have been investigated, its rates were measured in a variety of cultivars [54]. It was stated that the relationship between nitrogen fertilizer and rutin percent in the buckwheat was not significant [46]. In the experimental study, the effect of chemical fertilizers mainly of nitrogen fertilizers on qualitative content and especially a little bit of rutin mixture were investigated and it was reported that when less nitrogen is added to the soil, the higher polyphenolic rutin value is observed [55]. Nitrogen consumption stimulates the growth of plants, increases the duration of growth and by increasing the photosynthetic level increases the amount of assimilates provided to the lateral buds, this factor stimulates the growth of lateral buds and branches adverse events will occur. It has been reported that high nitrogen consumption, due to increased vegetative growth and decreased lignin, increases the risk of plant Lodging and affects the amount of active ingredient [21]. According to a report, they reported the use of $50 \mathrm{~kg}$ of nitrogen for optimal buckwheat growth. Kwang Jin Chang et al (2004) have conducted a study on 2 cultivars of buckwheat with 4 accumulations and 5 levels of fertilizer, and concluded that the highest rutin rate as $1887 \mathrm{mg}$ for $100 \mathrm{gr}$ of dry matter might be relevant to the treatment of $30 \times 60$, and the highest rutin rates in 2 cultivars were 1839 and $1934 \mathrm{mg}$ without using the fertilizer [48]. From the results obtained and other researchers, it can be stated that the interaction of all factors, including treatments and the environment, complicates complex relationships, which leads to new, usable and practical results. Corralation coefficient of plant traits indicated presented that stem rutin percent had a positive insignificant correlation with the grain yield (0.28). Above correlation showed that the increase in the yield indirectly influenced the increase of stem rutin (Table 4).

\section{Grain rutin percent (\%)}

Grain rutin percent has been affected by the year, and the interaction of the year with the replication and planting patterns was not significant but the year and sowing dates and nitrogen fertilizer had significant relationships. Considering the interactions of treatments, nitrogen fertilizer had significant relationships with the planting patterns and sowing dates but the planting patterns and sowing dates were not meaningfully correlated. Considering the relationships between treatments, sowing dates and planting patterns were of meaningless relationships while nitrogen fertilizer was significantly correlated (Table 2). As (Table 3) has already shown, the highest stem rutin percent computed as $0.007 \mathrm{mg}$ at $100 \mathrm{~g}$ of dry matter can be attributed to the treatment of $\mathrm{P}_{1} \mathrm{D}_{4} \mathrm{~N}_{2}$. Planting date is one of the important factors in the performance of plant metabolites and the reason is the adaptation of plant phenological stages to suitable environmental conditions, in this regard, the type of plant growth conditions is also very effective. The plant is an unlimited growth. On the fourth planting date, it created an interaction that increased the rutine storage of seeds. Results have shown that the fourth sowing date along with the planting pattern of $\mathrm{P}_{1}(50 \mathrm{~cm}$ mounds with 2 planting rows and intervals of $20 \mathrm{~cm}$ ) was the best choice for the plant vegetative conditions concerning the ecological, morphological and physiological aspects of the root for producing the maximum secondary metabolite (i.e. rutin) (Figure 6). Planting date is one of the important factors in the amount of rutin in buckwheat and in addition to the environmental conditions governing the time and place of cultivation, the amount of rutin accumulation is related to the type and Variety of buckwheat No planting date [56]. 
It is reported that the amount of rutin in bickwhaet seeds is in the range of 0.05 to 1.35 [57]. Reported Planting date and planting density have been reported to have a significant effect on the rutin content of buckwheat [38]. It has been reported that buckwheat sites affect the rutin percentage of rutin storage organs [10]. It has been reported that in all parts of the plant, the amount of rutin decreases with increasing plant age [41].

According to a report, the amount of seed rutin in buckwheat was less than other parts of the plant. [41,58]. Therefore, with the obtained result, it can be stated that the planting dates certainly play a significant role due to the change during the filing period and the amount of dry matter imported to the seeds. Therefore, the difference in the planting dates of this research Seed rutin is observed. Other researchers believed that the growth and environmental conditions along with the rutin extraction played the effective roles in varying the results of plant rutin percent [35]. Other researchers reported during seed ripening, rutin concentrations, rutinosidase activity, and 3GT activities increased in seeds, also rutin content in common and Tartary buckwheat seeds increased after pollination and peaks in mature seeds (several days after pollination) [59]. In a study to assess the resistance of wheat beech to environmental conditions, they reported that secondary metabolites produced in the plant increase plant resistance to adverse environmental conditions and therefore increase plant tolerance [11]. Based on the results of the researchers and the results of this research, it can be stated that in addition to the planting date, other factors such as plant growth habituation and interaction of other treatments and planting in summer (high temperature) have been effective in this experiment.

The uniform planting of plants and the proper distribution of plants in the field due to the lack of competition in obtaining water and food and creating an identical shade for land cover, especially in summer cultivation where evaporation from the ground is high, can protect soil moisture content and transmission cycle the nutrients are very efficient. In reviewing the amount of seed rutine in planting arrangement according to plant growth pattern (Indeterminat) and short growth period in planting arrangement $\mathrm{P}_{1}$, suitable conditions have been considered for storing secondary metabolites in plant organs and subsequent water transfer to seeds in time. The stems are reported to be narrower at high densities in wheat raisin cultivation [53]. In an experiment based on planting rows and density in wheat beech, it was reported that among the planting rows of $25 \mathrm{~cm}$ with a density of 200 seeds and rows of $12.5 \mathrm{~cm}$ with 400 seeds per square meter, the highest percentage of plant rutine in different organs was related to row $25 \mathrm{~cm}$ [42]. Seong et al (1998) conducted a study on the sowing dates and different planting distances (rows' width) concerning the buckwheat and explained that regarding the grain yield of this plant on April $14^{\text {th }}$ with 20 $\mathrm{cm}$ planting distances, the rutin storages in the grains were not meaningfully influenced by the given treatments [60]. Chirstensen et al (2010) showed the maximum rutin percent as 1.1 to $0.3 \mathrm{mg}$ [24]. According to various studies, the results on the grain rutin percent obtained by Chirstensen and his colleagues have been confirmed [61]. As reported, the grain rutin content of common buckwheat ranged between 5 and $58 \mathrm{mg} / 100 \mathrm{~g} \mathrm{dw}$ [26].

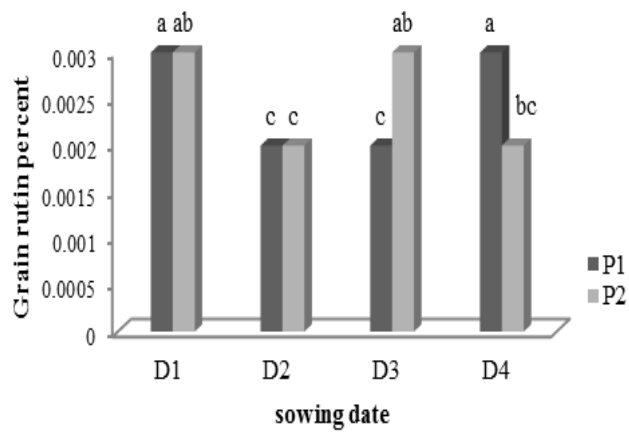

Figure 6. Interaction of planting pattern and sowing date of grain rutin

The use of nitrogen fertilizer is very important due to the conditions of this fertilizer and how to use the plants. In addition, cultivation in summer at higher temperatures doubles the importance of application and determining the required amount of its use. In examining the amount of seed rutine in the use of nitrogen as one of the important and essential nutrients, it is seen that the use of $50 \mathrm{~kg}$ of nitrogen has been able to increase photosynthetic and enzymatic activity of the plant and produce more active ingredient in seeds. It has been reported that the amount of rutin grain in buckwhaet is affected by nitrogen fertilizer and decreases with increasing nitrogen consumption of rutin grain [24]. It was reported that the use of $35 \mathrm{~kg}$ of nitrogen per hectare yields the highest rutin yield per grain [17]. The association between optimal nitrogen consumption with plant density and two-row planting arrangement in buckwheat has been reported [37, 62]. Honermier and Wagenbreth (2000) have seen the increase of rutin percent as 18 to $29 \%$ in the buckwheat using 0 to $90 \mathrm{Kg} \mathrm{ha}{ }^{-1}$ of nitrogen [47]. Corralation coefficient of plant traits indicated the positive correlation between rutin percent and grain yield (0.482). The above correlations showed that if the total number of grains increased in the plant, the grain yield and grain rutin percent would be enhanced (Table 4).

Table 4. Correlation analysis grain yield, leaf rutin, stem rutin, grain rutin and flower rutin

$\begin{array}{ccccc}\text { Grain } & \text { Leaf } & \text { Stem } & \text { Grain } & \text { Flower } \\ \text { yield } & \text { rutin } & \text { rutin } & \text { rutin } & \text { rutin }\end{array}$




\begin{tabular}{|c|c|c|c|c|c|}
\hline $\begin{array}{l}\text { Grain } \\
\text { yield }\end{array}$ & 1 & & & & \\
\hline $\begin{array}{l}\text { Leaf } \\
\text { rutin }\end{array}$ & $0.26 * *$ & 1 & & & \\
\hline Stem rutin & $0.288^{* *}$ & $-0.097^{\mathrm{n} . \mathrm{s}}$ & 1 & & \\
\hline $\begin{array}{l}\text { Grain } \\
\text { rutin }\end{array}$ & $0.482^{* *}$ & $0.061^{\mathrm{n} . \mathrm{s}}$ & $0.208^{* * *}$ & 1 & \\
\hline $\begin{array}{c}\text { Flower } \\
\text { rutin }\end{array}$ & $0.138^{\mathrm{n} . \mathrm{s}}$ & $0.130^{\mathrm{n} . \mathrm{s}}$ & $0.182 *$ & $-0.061^{\mathrm{n} . \mathrm{s}}$ & 1 \\
\hline
\end{tabular}

\section{Grain yield}

Combined analysis of variance of data showed that grain yield was not affected by the year. There were no interactions between the year and treatments, planting pattern, sowing date, nitrogen fertilizer and replications. Planting date and nitrogen fertilizer and planting pattern had significant relationships. Therefore, sowing date was significantly related with the planting pattern but it had no significant relationship with nitrogen fertilizer (Table 2). Interactions of three treatments indicated a difference at $1 \%$ level so that the most grain yield as $1967 \mathrm{~kg} \mathrm{ha}^{-1}$ was attributed to $\mathrm{P}_{2} \mathrm{D}_{1} \mathrm{~N}_{3}$ (Table 3). The most important characteristic studied in this experiment was the yield, which in fact involved nearly all the conclusions since the yield components might be finally related to this factor. Like other plants, final yield of buckwheat would be influenced by a variety of environmental and internal factors.

Many agricultural plants can prevent the severe decrease of yield by increasing the re-translocation of stored materials to the seeds as they face with an environmental tension. Potential of this retransfer introduced as an appropriate physiological index has been related to different elements such as genotype, nutrition and tension intensity. In other words, the plant depends on the materials stored in the aerial organs in such circumstances. Resources of assimilates for the maturity of seeds have been current photosynthesis, retransfer of assimilates stored in vegetative organs before the pollination and remotion of stored materials in vegetative organs after the pollination till the outset of seed linear growth that are generally called re-motion, retransfer and redistribution. Plants' yield in high temperature (summer) depends on all of these elements, especially the determination of suitable sowing date in order to specify carbon source and decrease the seeds' maturity period rather than the maturity speed. In this manner, the plants will be of high yield if they can significantly use the production elements and store more assimilates in their organs with regard to their growth conditions. In a test in Korea, the effect of planting time on growth and yield of buckwheat was investigated and reported that grain yield was $1190 \mathrm{~kg} \mathrm{ha}^{-1}$ in spring and
$1580 \mathrm{~kg} \mathrm{ha}^{-1}$ in summer [63]. Kalinova and Dadakova (2009) presented the yield of $1500 \mathrm{~kg} \mathrm{ha}^{-1}$ for the buckwheat [64].

Therefore, grain yield in the first sowing date $\left(D_{1}\right)$ can be attributed to better vegetative growth, canopy expansion and more suitable use of solar light as well as high photosynthesis in vegetative stages followed by more stored materials for the retransfer of assimilates during the maturity period of grains (Figure 7). In a trial on the planting date of buckwhaet, the best planting date for late spring sowing was reported [65]. It has been reported that buckwheat is suitable for planting in summer [40]. It has also been reported that the resistance of beech plants is due to the presence of secondary metabolite compounds [11]. (Figure 8). Evaluating the yield of 5 cultivars in Italy, the highest yield computed as $2379 \mathrm{~kg} \mathrm{ha}^{-1}$ was attributed to La Harpe [18]. The highest grain yield has been reported as $2699 \mathrm{~kg} \mathrm{ha}^{-1}$ for VL-7 [66].

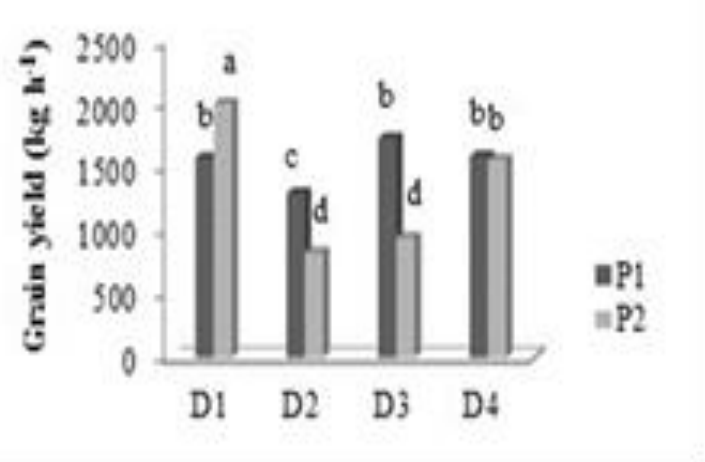

Figure 7. Interaction of planting pattern and $\mathrm{N}$ fertilizer on grain yield

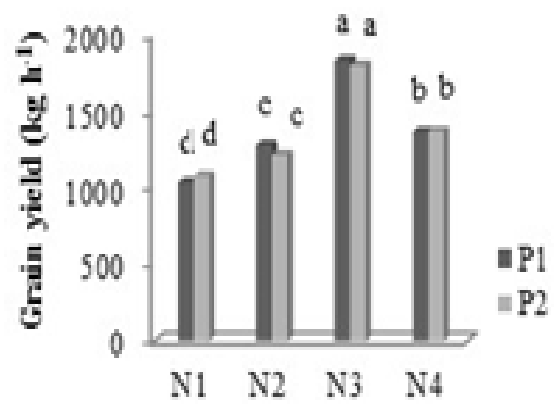

Figure 8. Interaction of planting pattern and sowing date on grain yield

Leaf area index and its distribution within the plant canopy were the main determinants of final light penetration into the plants that influenced photosynthesis, perspiration and accumulation of dry matters while being affected by the density and planting patterns. Plant yield was likely to be increased at the distance intervals between and on the rows 
because each bush used more sunlight and available sources in such conditions and as a result, more inputs were provided for the plant and more materials entered the destination. By decreasing the mound width from 60 to 50 $\mathrm{cm}$ and reducing the soil mass, soil situation would be more unfavorable for the plant growth and roots' expansion. On the other hand, one of its reasons might be the formation of thicker and more stable crust resulting from the severe evaporation during the summer planting period. Moreover, using the environmental sources, especially light in the dense planting pattern was fewer and consequently, the total yield would be decreased due to the low leaf area index and delayed establishment of plant vegetation. Considering the fixed density in the planting pattern of $\mathrm{P}_{2}$, the bush distribution on the mounds with the width of 60 $\mathrm{cm}$ in 3 rows with the distance intervals of $15 \mathrm{~cm}$ could decrease the internal species contest and enhance the share of each plant to absorb the light, water and nutrition from the roots as compared to the mounds with the width of 50 $\mathrm{cm}$ in 2 rows with the distance intervals of $20 \mathrm{~cm}$. Also, increasing the yield of plants between and on the rows was because of the fact that each phant used more sunlight and available sources in this situation. It has been reported that double-row planting in arid and semi-arid regions results in optimal nitrogen fertilizer consumption [37]. Considering the fact that increasing the amount of nitrogen fertilizer stimulated the vegetative growth and decreased the generative period and in summer, temperature effects accelerated the plant activities (reduction of vegetative and reproductive periods), the interaction of nitrogen fertilizer, planting date and plant growth type caused that using 100 $\mathrm{kg} \mathrm{N} \mathrm{ha}{ }^{-1}$, the plant was able to achieve the suitable leaf area index and the grains received more shares of photosynthetic materials. In the treatments of 0 and $50 \mathrm{~kg}$ of nitrogen, the plant did not obtain the favorable LAI and more photosynthesis, and as a result, biomass was produced before reaching the maturity of grains.

When plants were cultivated in the rows, their internal contest would be increased due to the plant morphological changes and increase of resources' number. Brunori et al (2005) examined 5 cultivars of buckwheat with 300 phant per square meter, the planting pattern having the $25 \mathrm{~cm}$ rows and $15 \mathrm{~kg} \mathrm{~N}$ and found a negative correlation between the yield and the harvest index [18]. In one study, buckwheat yield was reported to be $2170 \mathrm{~kg} \mathrm{ha}^{-1}$ with 50 $\mathrm{kg}$ of nitrogen [67]. It has been reported that the yield of buckwheat in the use of $120 \mathrm{~kg}$ of nitrogen is $2200 \mathrm{~kg} \mathrm{ha}^{-1}$ [62]. According to a report, they reported the use of $50 \mathrm{~kg}$ of nitrogen for optimal buckwheat growth [68]. The highest grain yield was reported with the use of $20 \mathrm{~kg}$ of nitrogen for wheat beech [69]. The correlation coefficients of studied traits and demonstrates that the grain yield had positive and significant correlations with leaf rutin percent (0.26), stem (0.28), seed (0.48), flower rutin percent $(0.13)$
(Table 4). Above correlations indicated the importance of yield and its relationship with the studied attributes. Since the effective material namely rutin may be regarded as a flavonoid compound and is more likely to be of fundamental application in the molecular structure as sugar, every factor leads to the increase in the openness duration of stomata existing in the plant leaves so that the production of carbohydrates and consequently, the yield and rutin rates will be increased.

\section{CONCLUSIONS}

What agriculture science is responsible for is to produce more high quality products in order to supply the increased population thereby eradicating food poverty and hunger. Considering that, cereal has been combined with our life and has been recognized as the most consumed food product in all countries worldwide. Role of buckwheat plant beside the cereal is very significant in order to meet the needs and shortage of food, and improve the quality value and healthy food. The increased need for food leads to consider this plant in the agriculture system worldwide while respecting the food health and security. According to the results of this study, the use of this plant is just for grain consumption, and the first planting date (June $20^{\text {th }}$ ), planting pattern $\left(\mathrm{P}_{2}\right)$ with the width of $60 \mathrm{~cm}$ along with three planting rows which are of the distance intervals of $15 \mathrm{~cm}$ (using Cereal sowing machine), and $100 \mathrm{~kg}$ nitrogen, are recommended. Overall, if the goal is using plant material to produce active ingredient (rutin) only as a medicinal plant for the extraction rutin plant, the fourth sowing date (August 5), planting pattern $\left(\mathrm{P}_{1}\right)$ with the width of $50 \mathrm{~cm}$ along with two planting rows which are of the distance intervals of $20 \mathrm{~cm}$ (using Planting with tworow working machine) and $100 \mathrm{~kg}$ nitrogen, are recommended. Therefore, buckwheat with nutritional characteristics, adaptation, good yield and as a new medicinal plant can enter the cultivation patterns in different regions of the world as a commercial source of rutin and a functional food.

\section{Acknowledgments: From Arak Islamic Azad University.}

Conflict of interest: The author declared no conflict of interest.

Financial support: This study did not have financial support.

Ethics statement: In this research, all ethical issues have been observed in the research.

\section{REFERENCES}


[1] Omidbaigi R, De Mastro G. Influence of sowing time on the biological behavior, biomass production, and rutin content on buckwheat. Ital $\mathrm{J}$ Agron. 2004;8(1):47-50.

[2] Small E. 54. Buckwheat-the world's most biodiversity-friendly crop? Food, Agric. Biodivers. 2017;18(2-3):108-23.

[3] Sarker U, Oka S. Drought stress enhances nutritional and bioactive compounds, phenolic acids and antioxidant capacity of Amaranthus leafy vegetable. BMC Plant Biol. 2018;18: 258. htpps://doi.org/10.1186/s12870-018-1484-1.

[4] Christa K, Soral-mietana M. Buckwheat grains and buckwheat products- nutritional and prophylactic value of their components - a review. Czech J Food Sci; 2008;26:153-62.

[5] Kalinova J, Dadakova E. Varietal and year variation of rutin content in common buckwheat (Fagopyrum esculentum Moench). Cereal Res. Commun; 2006;34:1315-21.

[6] Koja E, Ohata S, Maruyama Y, Suzuki H, Shimosaka $\mathrm{M}$, Taguchi G. Identification and characterization of a rhamnosyltransferase involved in rutin biosynthesis in Fagopyrum esculentum (common buckwheat). Biosci Biotechnol Biochem. 2018;82(10):1790-802.

[7] Ganeshpurkar A, Saluja AK. Protective effect of catechin on humoral and cell mediated immunity in rat model. Int immunopharmacol. 2018 Jan 1;54:261-6.

[8] Sengupta P, Sardar PS, Roy P, Dasgupta S, Bose A. Investigation on the interaction of Rutin with serum albumins: Insights from spectroscopic and molecular docking techniques. J Photochem Photobiol B. 2018 Jun 1;183:101-10.

[9] Cho YJ, Lee S. Extraction of rutin from Tartary buckwheat milling fractions and evaluation of its thermal stability in an instant fried noodle system. Food Chem. 2015;176:40-4.

[10] Drazic S, Glamoclija D, Ristic M, Dolijanovic Z, Drazic M, Pavlovic S, et al. Effect of environment of the rutin content in leaves of Fagopyrum esculentum Moench. Plant, Soil Environ. 2016;62:261-5.

[11] Germ M, Gaberščik A. The Effect of Environmental Factors on Buckwheat. Molecular Breeding and Nutritional. University of Ljubljana Aspects of Buckwheat. 2016:273-81.

[12] Georgiev V, Weber GJ, Kneschke EM, Denve PN, Bley T, Pavlov AI. Antioxidant activity and phenolic content of betalain extracts from intact plants and hairy root cultures of the red beetroot Beta vulgaris cv. Detroit Dark Red. Plant Foods Hum. Nutr. 2010;65(2):105-11. doi: 10.1007/s11130-010- 01566.
[13] Bernath J. Medicinal and aromatic plants, Mezo. Publication. Budapest; 2000;p. 667.

[14] Ratan P, Kothiyal P. Fagopyrum esculentum Moench (common buckwheat) edible plant of Himalayas: A Review. Asian J Pharm Life Sci. 2011;1(4):426-42.

[15] Murányi E. Effect of plant density and row spacing on maize (Zea mays L.) grain yield in different crop year. J Agric Environ Sci. 2015;2(1):57-63. https://doi.org/10.18380/SZIE.COLUM.2015.1.57.

[16] Lazányi J, László G. Second crop buckwheat in nyírség regions. University of Debrecen centre for Agricultural Sciences, 4032 Debrecen, böszörményi út 138. Hungary, correspondence analele universităţii din oradea, fascicula:Protecţia Mediului. 2009; 14:190-5.

[17] Hulihalli UK, Shantveerayya. Effect of planting geometry and nutrient levels on the productivity of Buckwheat. Int J Curr Microbiol Appl Sci. 2018;7(2):369-74.

[18] Brunori A, Brunon G, Baviello E, Marconi M, Colonna B, Ricci M. The yield of five buckwheat (Fagopyrum escitfennim moench) varieties grown in central and southern Italy. Fagopyrum; 2005;22:98102.

[19] Brunori A, Végvári G. Variety and location influence on the rutin content of the grain of buckwheat (Fagopyrum esculentum Moench and Fagopyrum tataricum Gaertn.) grown in Central and Southern Italy. In: Chai Y, Zhang Z (Eds) Advances in Buckwheat Research: Proceedings of the 10th International Symposium on Buckwheat, Northwest Agriculture and Forestry University, Yangling, China 2007a:349-57.

[20] $\mathrm{Hu}$ JY. Study of correlation between yield and seeding rate, seeding density, and plant survival rate in tartary. Fagopyrum; 2003;1:18-9.

[21] Wang C, Ruan RW, Yuan XH, Hu D, Yang H, Li Y, et al. Effects of nitrogen fertilizer and planting density on the lignin synthesis in the culm in relation to lodging resistance of buckwheat. Plant Prod Sci. 2015;18(2): 218-27.

[22] Salehi A, Fallah S, Kaul HP. Broiler litter and inorganic fertilizer effects on seed yield and productivity of buckwheat and fenugreek in row intercropping. Arch Agron Soil Sci. 2017 Jul 3;63(8):1121-36.

[23] Hodge A, Fitter AH. Microbial mediation of plant competition and community structure. Funct Ecol. 2013;27(4):865-75.

[24] Christensen KB, Kaemper M, Loges R, Fretté X, Christensen LP, Grevsen K. Effects of nitrogen fertilization, harvest time, and species on the concentration of polyphones in aerial parts and seeds 
of normal and tartary buckwheat (fagopyrum sp.). Euro J Hort Sci; 2010;75(4):153-64.

[25] Li HC, Bozhang L, Zi X. Inter varietals variations of rutin content in common buckwheat flour (Fagopyrum esculentum Monch). Transgenic Res. 2008;17(1):12132.

[26] Brunori A, Baviello G, Zannettino C, Corsini G, Sandor G, Vegvari G. The use of tartary nutritional profile of buckwheat 15 buckwheat whole flour for bakery products: recent experience in italy. Annals of the University Dunarea De Jos Galati Fascicle V1Food Technology; 2010;34:33-8.

[27] Park NI, Li X, Uddin MR, Park SU. Phenolic compound production by different morphological phenotypes in hairy root cultures of fagopyrum tataricum gaertn. Arch Biol Sci; 2011;63:193-8.

[28] Kreft I, Fabjan K, Yasumoto K. Rutin content in buckwheat (Fagopyrum esculentum Moench) food materials and products. Food Chem. 2006;98:508-12.

[29] Kavacevic M, Rode J. Determination of rutin in buckwheat leaves. Chromatography and Hyphenated Techniques. Bled. 1998;153.

[30] Kreft S, Štrukelj B, Gaberščik A, Kreft I. Rutin in buckwheat herbs grown at different UV-B radiation levels: comparison of two UV spectrophotometric and an HPLC method. J Exp Bot. 2002 Aug 1;53(375):1801-4.

[31] Vajic, UJ, Grujic-Milanovic J, Zivkovic J, Savikin K, Godevac D, Miloradovic Z, et al. Optimization of extraction of stinging nettle leaf phenolic compounds using response surface methodology. Ind Crops Prod. 2015; 74:912.

[32] Deng J, Xu Z, Xiang C, Liu J, Zhou L, Li T, et al. Comparative evaluation of maceration and ultrasonicassisted extraction of phenolic compounds from fresh olives. Ultrason. Sonochem. 2017 Jul 1;37:328-34. https://doi.org/10.1016/j.ultsonch.2017.01.023.

[33] Đurendić-Brenesel M, Popović T, Pilija V, Arsić A, Milić M, Kojić D, et al. Hypolipidemic and antioxidant effects of buckwheat leaf and flower mixture in hyperlipidemic rats. Bosn J Basic Med Sci. 2013;13(2):100-8.

[34] Habtemariam S. Antioxidant and rutin content analysis of leaves of the common buckwheat (Fagopyrum esculentum Moench) grown in the United Kingdom: a case study. Antioxidants. 2019;8(6):160.

[35] Borovaya SA, Klykov AG. Some aspects of flavonoid biosynthesis and accumulation in buckwheat plants. Plant Biotechnol Rep. 2020 Apr;14(2):213-25. doi: 10.1007/s11816-020-00614-9

[36] Rauf M, Yoon H, Lee S, Lee MC, Oh S, Choi YM. Evaluation of Fagopyrum esculentum Moench germplasm based on agro-morphological traits and the rutin and quercetin content of seeds under spring cultivation. Genet Resour Crop Evol. 2020:1-9.

[37] Ying Jiang X, Wang Z, Zeng J, Han M, Schiavon C, Tang. Performance of common buckwheat (Fagopyrum esculentum M.) in response to row spacing under ridge and furrow cropping systems in a semiarid region of China. J Arch Agron Soil Sci. 2018; 64(13):1807-17.

[38] Podolska G. The effect of habitat conditions and agrotechnical factors on the nutritional value of buckwheat. In: Zhou M, Kreft I, Woo SH, Chrungoo $\mathrm{N}$, Wieslander $\mathrm{G}$ (eds) Molecular breeding and nutritional aspects of buckwheat. Elsevier Science, London. 2016:283-97.

[39] Omidbaigi R, Zakizadeh H. Influence of nitrogen fertilization and plant density on grain yield of buckwheat (Fagopyrum esculentum). Indian J Agric Sci. 2002;72:484-5.

[40] Babu S, Yadav G S, Ragha VS, Avasthe RK, Anup D, Mohapatra KP, et al. production technology and multifarious uses of buckwheat (fagopyrum spp.). indian J Agron. 2018;63(4):415-27.

[41] Mariotti M, Macchia M, Cerri D, Gatta D, Arduini I, Saccomanni G. Rutin content in the forage and grain of common buckwheat (Fagopyrum esculentum) as affected by sowing time and irrigation in a Mediterranean environment. Crop Pasture Sci. 2020 Mar 16;71(2):171-82.

[42] Kalinová J, Dadáková E. Influence of sowing date and stand density on rutin level in buckwheat. Cereal Res Commun. 2013 Jun 1;41(2):348-58.

[43] Hagels H, Wagenbreth D, Schilcher H. Phenolic compounds of buckwheat herb and influence of plant and agricultural factors (Fagopyrum esculentum Moench and Fagopyrum tataricum Gartner). The 6th iinternational symposium on buckwheat. Curr Adv Buckwheat Res. 1995;115:801-9.

[44] Ghouzhdi HG, Sahraroo A, Yavari AR, Amerian MR. Effect of mist, irrigation and plant density levels on rutin content of common buckwheat (Fagopyrum esculentum Moench.). J Food Agric Environ. 2009 Jan 1;7:179-81.

[45] Wagenbreth D, Hagels H, Schilcher H, Pank F. Characterization of buckwheat cultivars and gene bank material for rutin content and growth parameters. Proceedings. Int Symp. Breeding Research on Medicinal and Aromatic Plants, Quedlinburg. Germany, Beitrage- Zur-ZurchtungsforschungBundesanstalt- Fur- Zurchtungsforschung- an KulTurpflanzen; 1996;2(1):95-8.

[46] Marquard R, Kroth E. An bau und qualitatsnforderungenausgewahlter arzneipflanzen. Agri Media, Bergen/Dumme; 2001:64-71. 
[47] Honermeie B, Wagenbreth D. Production studies on the suitability of buckwheat (fagopyrum esculentum Mornch) for dietetic and pharmaceutical use. J Med Aromat Plants; 2000;5:154-9.

[48] Kwang JC, Jong IP, Byoung JP, Soon KH, Yang SL, Cheal HP. Effects of Planting Density and Fertilization on Yield and Rutin Content in Tartary Buckwheat:; Proceedings of the 10th international symposium on buckwheat, 2004.

[49] Jinfeng G, Shouqiang A, Xiaoli G, Dongli G, Yan C, Baili F. Effects of sowing at different time on flavonoids content of buckwheat. In: Proceedings of 10th International Symposium on Buckwheat, August 14-18, Northwest A \& F Univ., Yangling, China, 2007:pp. 338-41.

[50] Adeleyda M, Lumingkewas W, Koesmaryonob Y, Sandra A, Azizc I, Sugimoto H. The Influence of Temperature to Rutin Concentration of Buckwheat Grains in Humid Tropic. Int J Sci Basic Appl Res. (IJSBAR). 2015; 20(1):1-9.

[51] Suzuki T, Morishita T. Bitterness Generation, rutin hydrolysis, and development of trace rutinosidase variety in tartary buckwheat (In) Molecular breeding and nutritional aspects of buckwheat edited by Meiliang Zhou, Ivan Kreft, Sun-Hee Woo, Nikhil Chrungoo and Gunilla Wieslander. 2016:345-53.

[52] Ahmed A, Khalid N, Ahmada N, Abbasin A, Latif MSZ, Randhawa AM. Phytochemicals and biofunctional properties of buckwheat. J Agric Sci. 2013: 1-21.

[53] Tolaini V, Fiore AD, Nobili C, Presenti O, Rossi PD, Procacci S, et al. Exploitation of Tartary buckwheat as sustainable ingredient for healthy foods production. Agric Agric Sci Procedia. 2016;8:455-60.

[54] Kim SU, Kim SK, Park CH. Introduction and nutritional evaluation of buckwheat sprouts as a new vegetable. Food Res Inter; 2004;37:319-22.

[55] Heimler D, Romani A, Ieri F. Plant polyphenol content, soil fertilization and agricultural management: A review. Eur. Food Res Technol. 2017;243(7):1107-15.

[56] Hyun DY, Rauf M, Lee S, Ko HC, Oh S, Lee MC. Comparison of growth characteristics and flavonoids content by different cultivation seasons in buckwheat germplasm. Korean J Plant Res. 2018;31:489-97.

[57] Bai CZ, Feng ML, Hao XL, Zhong QM, Tong LG, Wang ZH. Rutin, quercetin, and free amino acid analysis in buckwheat (Fagopyrum) seeds from different locations. Genet Mol Res. 2015;14(4):19040-8.

[58] Katsu K, Suzuki R, Tsuchiya W, Inagaki N, Yamazaki T, Hisano T, et al. A new buckwheat dihydroflavonol 4-reductase (DFR), with a unique substrate binding structure, has altered substrate specificity. BMC Plant Biol. 2017;17: 239.

[59] Suzuki T, Honda Y, Funatsuki W, Nakatsuka K. Purification and characterization of flavonol 3glucosidase, and its activity during ripening in Tartary buckwheat seeds. Plant Sci. 2002;163:417-23.

[60] Seong JD, Park YJ, Kim HT, Kim GS, Park CK, Kwack YH. Effect of seeding date and row with on the grain yield and rutin content of fagopyrum esculentum in Youngman areas of Korea. J Indus Crops Sci. 1998;40(1):19-22.

[61] Kim SU, Zaidul T, Suzuki Y, Mukasa N, Hashimoto $\mathrm{S}$, Takigawa T. Comparison of phenol compositions between common and tartary buckwheat (fagopyrum) sprouts. Food Chem. 2008;110:814-20.

[62] Inamullah I, Ayub M, Khan AA, Anwar S, Khan SA. Response of common buckwheat to nitrogen and phosphorus fertilization. Sarhad J. Agric. 2012;28(2):171-8.

[63] Jung GH, Kim SL, Kim MJ, Kim SK, Park JH, Kim $\mathrm{CG}$, et al. Effect of sowing time on buckwheat (Fagopyrum esculentum Moench) growth and yield in central Korea. J Crop Sci Biotechnol. 2015;18:285-91.

[64] Kalinova J, Vrchotova N. Level of catechin, myricetin, quercetin and isoquercitrin in buckwheat (Fagopyrum esculentum Moench), changes of their levels during vegetation and their effect on the growth of selected weeds. J Agric Food Chem. 2009 Apr 8;57(7):2719-25

[65] Mariotti M, Masoni A, Arduini I. Forage and grain yield of common buckwheat in Mediterranean conditions: response to sowing time and irrigation. Crop Pasture Sci. 2016 Oct 7;67(9):1000-8.

[66] Hore D, Rathi RS, Collection M. Cultivation and characterization of buckwheat in northeastern region of India national bureau of plant genetic resources. Regional Station, Brainpan. 2002;793-8.

[67] Sytar O, Kosyan A, Taran N, Smetanska I. Anthocyanin's as marker for selection of buckwheat plants with high rutin content. Gesunde Pflanzen. 2014 Dec 1;66(4):165-9. doi: 10.1007/s10343-0140331-z

[68] Tummaramatti S, Hegde L, Hosamani RB, Sampaganvi SS. Effect of bio-fertilizers on growth, yield and quality of buckwheat (Fagopyrum esculentum Moench). Environ Ecol. 2016;4(3):125861.

[69] Saha A, Sinha AC, Samanta S. Response of integrated nutrient management on nutrient content as well as uptake of buckwheat varieties and its residual effect on mung bean under Terai Region of West Bengal, India. Int J Curr Microbiol Appl Sci. 2017;6(11):3613-20. 